\title{
UC agriculture programs: Investing in California's future
}

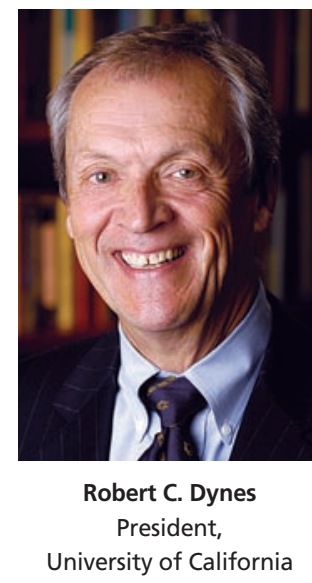

$W^{\text {ith the state facing a tough }}$ budget year, this is a time for the University of California to cut costs and increase efficiencies. But given UC's transformative impact on California over 140 years, and given eroding state support for UC in recent decades, this also is a time for the University and its stakeholders to send a message to Sacramento: Funding for UC's missions of research, education and public service is an investment in the future of this state. California needs to sustain the innovative excellence that fuels our economy, educates our future leaders and safeguards our quality of life.

No one knows this better than California's agricultural community, and nothing demonstrates UC's impact more dramatically than the programs of our Agriculture and Natural Resources (ANR) division.

In my 4 years as UC president, I have visited growers from Redding to El Centro. At every stop, I have heard about UC's importance from family farmers. Half Moon Bay nurseryman Jack Pearlstein told me in 2005, "Without UC science, California will no longer be an agricultural state." Coachella Valley date grower Albert Keck told me last month, "We see UC's direct impact in agriculture every day."

Along the way, I have learned that UC and California agriculture have a common entrepreneurial spirit and a shared purpose in our three mission areas.

Innovation through research. UC has led the state and the nation into a new era of what I call " $R, D$ and D": research, development and delivery of innovations to end-users. UC scientists on our campuses and county-based Cooperative Extension advisors are carrying out R, D and D to benefit agriculture in every corner of California.

I have seen firsthand how Central Valley almond and walnut farmers reduce airborne dust (and save fuel) by using new conservation tillage methods and more-efficient harvesters developed through UC research.

I have learned how UC integrated pest management programs curb chemical use on large Central Coast farms and improve water quality in backyard gardens from San Diego to Redding.

I have spoken to families in Los Angeles County who are eating more nutritious meals and reducing their risk of diabetes and other illnesses thanks to UC consumer education programs.

I have met with forest managers in the Sierra Foothills and rice farmers in the Sacramento Valley who are using UC land conservation practices to boost production, expand wildlife habitat and reduce carbon emissions.
And right now, you are reading one of our oldest and most successful models of R, D and D. California Agriculture disseminates timely, peer-reviewed research, and in this edition you will find articles about the invasive light brown apple moth, methyl bromide alternatives, sustainable production practices, and food safety and environmental quality.

Opportunity through education. Research creates ideas; education creates the next generation of creators. UC students working in ANR areas are learning to be innovators, like UC Santa Cruz graduate student Marcos Lopez, who is studying how the restructuring of California strawberry production, including the phase-out of methyl bromide, affects local labor markets and community redevelopment.

I am gratified at how industry visionaries like Bill Pauli, past president of the Farm Bureau Federation, have been our partners in pushing for an overhaul of K-12 science and math education to raise the tech literacy of future workers. And UC takes special pride in our 4-H Youth Development program, which has a long tradition of grooming California's future agriculture leaders.

Public service and public awareness. In many respects, UC and California agriculture have been the victims of our own success. The rest of the world marvels at our entrepreneurial excellence and envies the success it has generated. Here at home, many Californians do not fully grasp UC's impact on this state, and many think the plentiful food they eat originates at Ralph's or Safeway.

In concert with our mission of public service, we must work together to raise public awareness. We must remind our elected officials that California's $\$ 32$ billion agricultural sector produces more than 350 commodities and employs $7 \%$ of the state's private-sector workforce. And we must remind them that UC helps make that possible by giving California farmers and ranchers the innovative technologies, research breakthroughs and real-world solutions they need to compete globally and farm more sustainably.

UC's commitment to bolstering California agriculture and preserving our natural resources is stronger than ever, especially with Dan Dooley in place as our new ANR vice president. But we must have the necessary support to fulfill that commitment. I am making the case for that support as vigorously as I can, and I need your help.

If UC has had an impact on your own life, I invite you to join "UC for California," a dynamic advocacy support network that mobilizes the UC community. The months ahead are critical. Please visit www.ucforcalifornia.org, sign up as a UC friend, and let your elected officials know why an investment in UC is an investment in California's future. Thank you. 